\title{
Development of Rural Ecotourism on the Yurshinsky Island of Rybinsk Reservoir
}

\author{
Svetlana Zamana ${ }^{1}$, Olga Sorokina ${ }^{1, *}$, Dmitriy Shapovalov ${ }^{1}$, Alexandr Fomin ${ }^{1}$, Larisa \\ Petrova $^{1}$, Yulia Potanina ${ }^{2}$, and Ilya Fomkin ${ }^{1}$ \\ ${ }^{1}$ State University of Land Use Planning, 15, Kazakova ave., Moscow, 105064, Russia \\ ${ }^{2}$ Lomonosov Moscow State University, GSP-1, Leninskie Gory, Moscow, 119991, Russia
}

\begin{abstract}
Agroecotourism is a relatively young branch of tourist industry in our country, at the same time it has become very popular abroad. The article considers some problems related to the development of rural ecotourism on the Yurshinsky island of Rybinsk reservoir. Various landscapes can be seen on the Yurshinsky island, escaping flowage of the Rybinsk reservoir area, where unique samples of Russian nature have remained untouched. The territory of island makes 792 hectares, half of its land is occupied by woods, and now all island has a status of specially protected area. Moose breeding farm is recommended to be established as the object of rural ecotourism on the Yurshinsky island, as its operation allows the tourist season last all-year-round. Ecological conditions of the territory need to be assessed before the organization of a moose farm and other objects of agroecotourism. Therefore we selected several soil samples to perform chemical analysis as the soil represents the knot of interrelations in biosphere and a lack or surplus of both vital, and toxic chemical elements in the soil will lead to their lack or surplus in plants grown up on such soils and in animal organisms which eat the given plants.
\end{abstract}

\section{Introduction}

Stable growth of urban residents and decline in rural population aggravates social problems of villages and negatively affects the stability of local development. Improving stable rural development is linked to the decision of necessary and interrelated social, economic and environmental problems. For example, low incomes of population residing in rural areas result in:

- large percentage of low-educated people, dysfunctional families, aged population;

- growing communication distance between generations and disappearance of cultural traditions;

- extremely intense labor migration;

- treatment of natural environment as a commodity by local population.

The measures contributing to income growth of agricultural households can confront social, economic and environmental problems in rural areas. In our view, the incomes of local

* Corresponding author: sorokinaoa81@gmail.com 
population to a certain extent can be influenced by involving it in the arrangement of recreational services on rural lands, i.e. of agroecotourism.

Agroecotourism is a recently developed branch of tourist industry in our country, at the same time it has become very popular abroad. It is of great interest to the public because of low costs and greater affinity with the nature, in comparison with other kinds of recreational activities. Such tourist projects can become a new income source for village households. They can create demand for local goods (especially food products) and services and, thus, give more chance for extra earnings. Agroecotourism is also capable to provide cultural and social benefits to local communities. So, intercultural and social ties between local residents and tourists can be reinforced. Rural population and incoming tourists begin to realize the value of cultural heritage of a specific territory and the necessity of its protection. The local community will become stronger thus, and the infrastructure and service industry will be operated more effectively and become more viable. The development of agroecotourism can contribute to find new potentials for local economy, keep the heritage and social values and thus to raise life quality.

Ecotourism is a form of tourism involving traveling and visiting natural areas aimed at the dialogue with the nature, the discover of new natural phenomena, animals and plants [1]. It often includes traveling to wildlife reserve, national parks and other protected territories. It attracts people with rich experience, adventure holidays and possibility to plunge into new conditions; thus it is absolutely unessential to have previous experience of hikes or excellent physical conditions.

The term «ecotourism» has been put into practice in the early 1980 s of the 20 th century. There is no single definition of ecotourism. The Ecotourism Society defines it as responsible travel to natural areas promoting wildlife management and improving wellbeing of local population; the World Wildlife Fund (WWF) points, that ecotourism means travelling to the places with rather intact nature in order to get an impression of natural and cultural-ethnographic features of an area provided the integrity of ecosystem is not damaged and economic conditions are created at which the management of wildlife and natural resources becomes favorable to local population [2].

The following ecotourism principles are adopted as its main features:

- Discovering wildlife and local customs and culture as well;

- Inducing desire to communicate with wildlife;

- The minimum negative ecological and sociocultural consequences, maintenance of ecological stability of environment;

- Contribution to natural resources and local cultural environment protection;

- Ecological education;

- Income generation by local residents from tourist activities providing economic inducements for them to wildlife protection of their lands;

- Provision of social and economic development of local territories.

Ecotourism assumes, that local residents continue to live in protected areas, to maintain a previous life, to be engaged in the traditional economic activities providing environmentally sound mode of wildlife management, and at the same time render support services for ecotourists $[2,3]$. This provides certain income to the locals and promotes social and economic territorial development.

\section{Materials and methods}

Ecotourism is considered to have positive ecological, welfare and economic benefits of tourism and is based on sustainable development principles.

The research studies demonstrate, that tourism is one of the important parts of economic development in Rybinsk municipal district (the Yaroslavl region) including Yurshinsky 
island, abetted by convenient geographical location (proximity to Moscow and St.Petersburg), available highways, water routes and railroads, rich cultural heritage (old temples, manses), various natural landscapes of the Rybinsk reservoir and the Volga river basins with multiple small rivers and pure springs. In this area multipurpose tourist zones are arranged in the areas with specially protected status (state wildlife reserves, natural and historical areas with protected status). The redevelopment of the church in the name of Smolensk Icon of Mother of God and New Jugsko-Dorofeev monastery, as well as new objects to meet service demand of population is envisaged on Yurshinsky island. All this determines agroecotourism to become the basic direction of territorial development of Yurshinsky island, focused both on internal, and external tourism branches [4].

Successful implementation of agroecotourism requires the following steps to be accomplished:

- Working out tourist itineraries;

- Developing areas attracting tourists;

- Arrangement of tourist objects;

- Inducements for hoteliers;

- Development of a roadside amenities;

- Support and promotion of developed projects [5, 6].

With reference to the above mentioned, the Yurshinsky island represents unique long term possibilities of creating multifunctional agroecotourism zone.

Various landscapes can be seen on the Jurshinsky island, escaping flowage of the Rybinsk reservoir area, where unique samples of the untouched Russian nature have remained. There are coniferous, small-leaved and mixed forests on this island, meadows and marshes with trees, bushes, grasses, mosses and lichens.

Birch forest includes two kinds of birch (silver and downy birches), bilberry, wartybark euonymus, fly honeysuckle, wolf's claws, wood-sorrel oxalis, may lily, consumption weed, Paris herb, lily of the valley. Dwarf wood cereals, raspberry, juniper prevail and grow in the grass layer of pine wood. It is possible to meet aye-green, cowberry, lichens, mosses at the pine forest edge. Wild forest strawberry, common Saint-John's wort, base vervain, lesser starwort grow in the mixed wood. Blueberry, cloudberry, cranberry, sphagnum, marsh tea, marsh butterbur, sweet gale, sheathed cotton sedge, cowberry grow in marsh areas.

Former agricultural island lands where plowing up was stopped by present time; grass meadows were formed with the prevalence of wild grasses with dense birch undergrows. Such healing over can further lead to the sites of birch wood. It is possible to consider forest belts including adult birches, bordering former sites of arable lands in the vicinities of villages Lipnjagi, Bykovo, Antonovo and Yurshino, as fragments of a cultural island landscape.

Now, when young generation studies plants and animals from books and the Internet more often, it is especially important a direct dialogue of a person with the nature in the habitat. Such dialogue can be organized, as it was already marked, by means of agroecotourism. And the most interesting object of such tourism can be a moose breeding farm arranged on Yurshinsky island. The tourist season in such a farm can last all year around.

In the Soviet Union moose farms and moose breeding was perceived as alternative branch of animal industries, and it is now clear, that it can be the object of tourism (for example, GNIBUKO «Sumarokovsky» moose farm near Kostroma) (Figure 1,2). Research on moose domestication shows [6], that moose do not require domestication, they are ready domestic animals if correctly grown up and brought up. With correct domestication moose are well domesticated and do not represent more danger than other pets. 


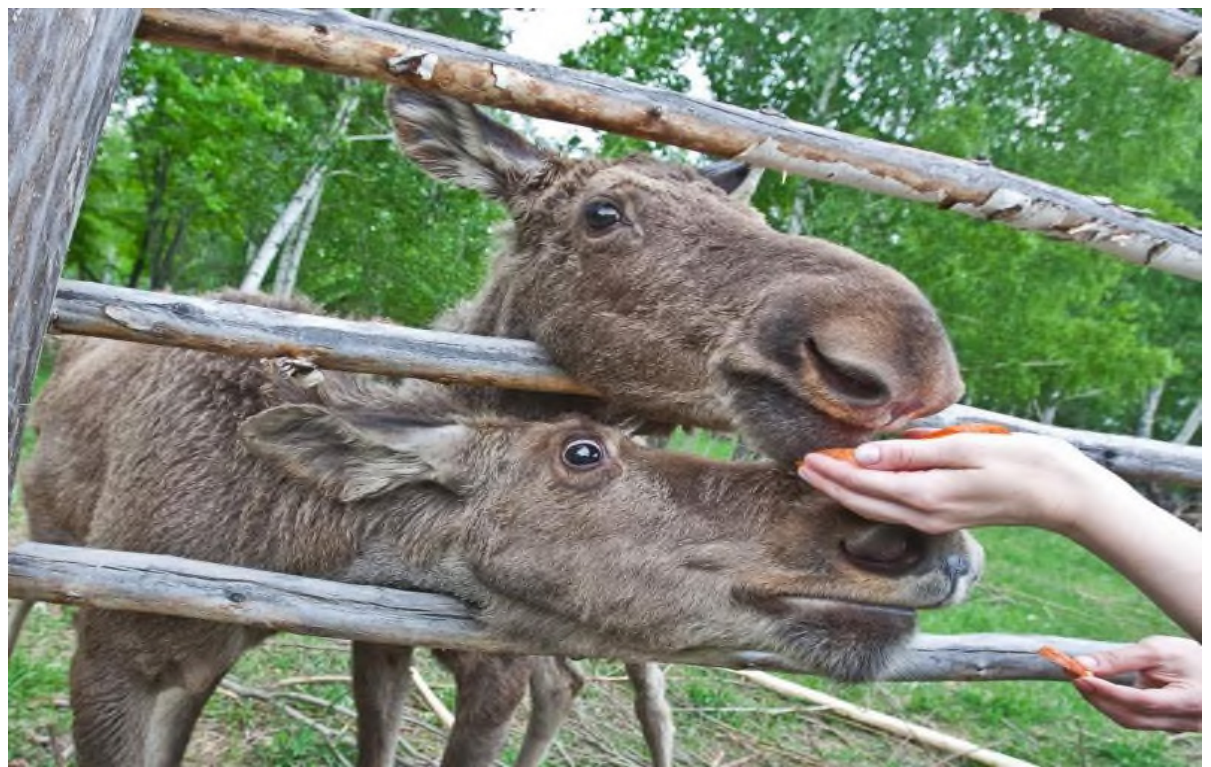

Fig. 1. Moose as domestic animal.

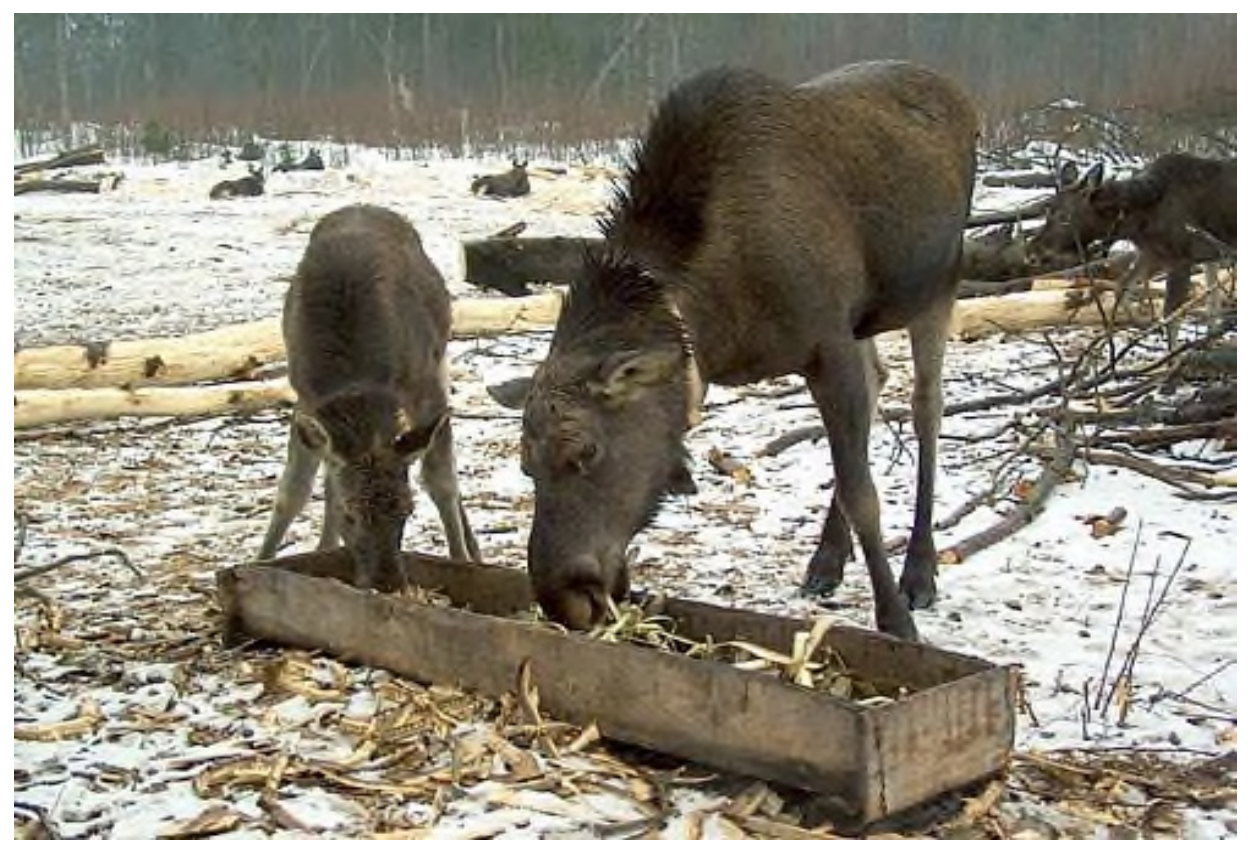

Fig. 2. Moose livery services in winter time.

Moose are considered as one of the most easily domesticated wild animals though they hardly bear captivity and often get ill. Therefore the herd in a moose farm should be in free pasturage, i.e. any adult animal can freely come on a farm and leave it. During snow period moose are contained in a winter wood allotments, and beginning from April all animals are transferred to a summer camp and the period of fawning begins.

Unique ability to eat various wood and bush vegetation involves moose adoption to various climatic conditions, vegetation and grassy forages. In the winter they are not inclined to long migration if they are not disturbed strongly by hunters and forage 
shortages. Every morning they go to an habitual place of supplementary feeding. Porridge from the grounded boiled oats with warm water is usually placed in feeding troughs. For example, the territory of «Sumarokovsky» farm makes up 200 hectares where 40 moose live now.

The territory of Yurshinsky island makes 792 hectares, half of it is occupied by wood, and now all island territory has a status of specially protected area [7]. The organization of moose farm on Yurshinsky island is quite possible.

Visitors of moose farm can be offered not only photos with animals, but also feeding them, and trying moose milk (from May till September), by means of which many gastroenteric diseases [8-9] are successfully treated.

The medical effect of moose milk is caused by its high biochemical activity, the source of irreplaceable and replaceable amino acids. The content of such elements as silicon, magnesium, manganese, molybdenum, cobalt, surpasses their content in cow milk. Female moose can give from 2-6 1 of milk a day, milking operation is provided by means of devices, and manually. Frozen milk can be stored long time without loss of medical properties [8-9].

The organization of a moose farm, as well as other objects of agroecotourism requires making estimates of ecological conditions of territory, therefore we selected several soil samples to perform chemical analysis as the soil represents the knot of interrelations in biosphere and a lack or surplus of both vital, and toxic chemical elements in soil will lead to their lack or surplus in plants grown up on such soil and in animal organisms which eat the given plants [10-12].

The student's team selected samples of sod-low podzolic soils in three points: Plot №1 a potato field on a glade of Dello country estate; Plot №2 - the slope of a barren riverside; Plot №3 - a vegetable garden of a local resident (Fig. 3).

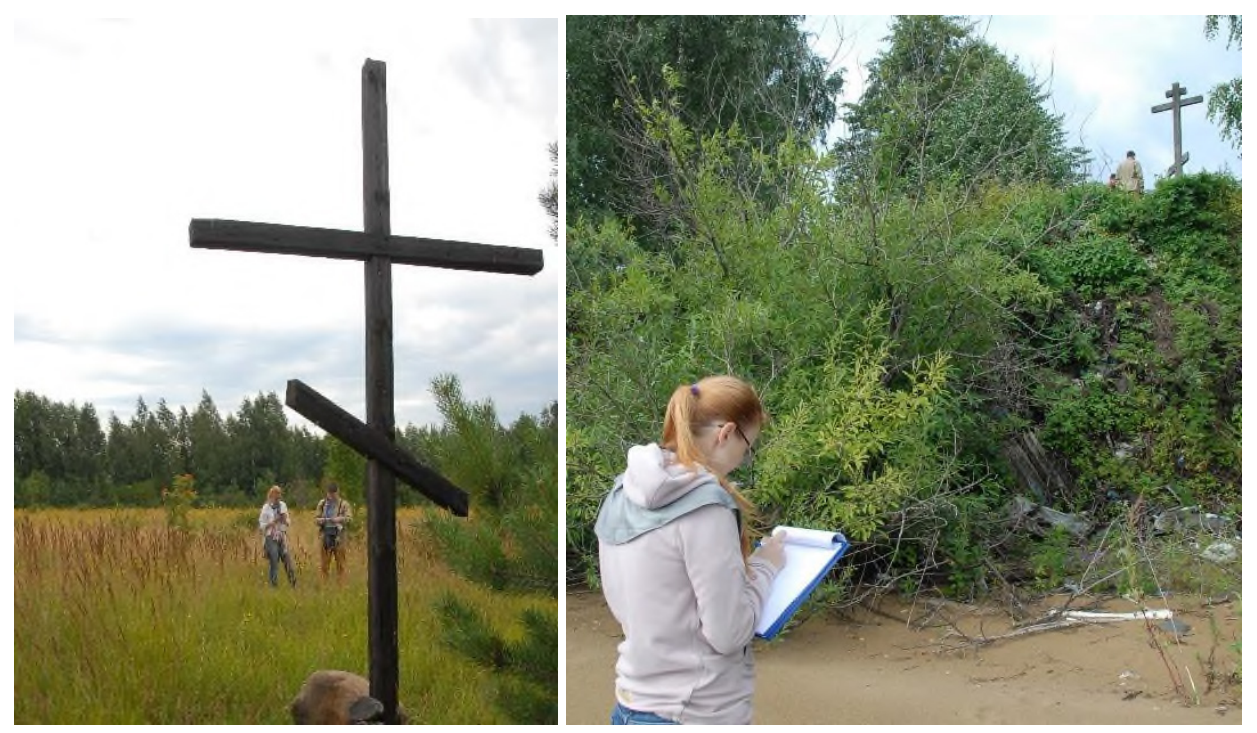

Fig. 3. Student's team works on Yurshinsky island.

\section{Results}

Agrochemical soil indicators and total composition of especially dangerous chemical elements are presented in Tables 1 and 2 . 
Table 1. Agrochemical soil indicators.

\begin{tabular}{|c|c|c|c|c|c|c|c|c|c|}
\hline \multirow{2}{*}{$\begin{array}{l}\text { No } \\
\text { of } \\
\text { plot }\end{array}$} & \multirow[t]{2}{*}{$\mathrm{pH}_{\mathrm{kc1}}$} & \multirow{2}{*}{$\begin{array}{l}\text { Org. } \\
\text { matter, } \\
\%\end{array}$} & \multirow{2}{*}{$\begin{array}{l}\mathrm{P}_{2} \mathrm{O}_{5} \\
\mathrm{mg} / \mathrm{kg}\end{array}$} & \multirow{2}{*}{$\begin{array}{l}\mathrm{K}_{2} \mathrm{O}, \\
\mathrm{mg} / \mathrm{kg}\end{array}$} & \multicolumn{5}{|c|}{ Labile soil microelements, $\mathrm{mg} / \mathrm{kg}$} \\
\hline & & & & & $\mathrm{Mn}$ & Co & $\mathrm{Cu}$ & $\mathrm{Zn}$ & Mo \\
\hline 1 & 4.9 & 0.53 & 333 & 76 & 12.0 & $<2$ & $<2$ & 2.6 & $<1$ \\
\hline 2 & 5.0 & 0.56 & 776 & 117 & 9.3 & $<2$ & $<2$ & 2.1 & $<1$ \\
\hline 3 & 5.8 & 1.01 & 446 & 135 & 13.5 & $<2$ & $<2$ & 2,8 & $<1$ \\
\hline
\end{tabular}

Table 2. Total composition of toxic chemical elements.

\begin{tabular}{|l|l|l|l|l|}
\hline \multirow{2}{*}{ No of plot } & Lead & Arcenic & Cadmium & Mercury \\
\cline { 2 - 5 } & $\mathrm{mg} / \mathrm{kg}$ & 4.0 & 0.1 & $<0.1$ \\
\hline 1 & 5.3 & 3.5 & 0.2 & $<0.1$ \\
\hline 2 & 32.2 & 3.5 & 0.1 & $<0.1$ \\
\hline 3 & 19.2 &
\end{tabular}

Table 1 apparently shows that the soils of Plot 1 and 2 are medium acid $\left(\mathrm{pH}_{\mathrm{kc} 1}\right.$ 4.9-5.0) and needs lime application, the soil of Plot $3\left(\mathrm{pH}_{\mathrm{kc} 1} 5.8\right)$ is close to neutral. The content of organic substance (the important indicator of its potential fertility) is low (less than $2 \%$ ); very high content of mobile phosphorus $(333-776 \mathrm{mg} / \mathrm{kg})$ is observed; low $(76 \mathrm{mg} / \mathrm{kg})$ and average $(117-135 \mathrm{mg} / \mathrm{kg})$ is the content of exchangeable potassium; a low content of mobile (accessible to plants) manganese forms $(9.3-13.5 \mathrm{mg} / \mathrm{kg})$ is observed; an average content of mobile forms of copper (less than $2 \mathrm{mg} / \mathrm{kg}$ ), zinc $(2.1-2.8 \mathrm{mg} / \mathrm{kg}$ ) and cobalt (less than 2 $\mathrm{mg} / \mathrm{kg}$ ) are provided. Very high content of mobile forms of phosphorus, apparently, is connected with their soil application «as a reserve» by collective farm complex agrochemical services provided on the island aimed at field reclamation.

Table 2 apparently shows that total (general) content of especially dangerous heavy metal - mercury $(<0.1 \mathrm{mg} / \mathrm{kg})$ is considerably below maximum concentration limit $(2.1$ $\mathrm{mg} / \mathrm{kg}$ ), the total content of other heavy metal - cadmium $(0.1-0.2 \mathrm{mg} / \mathrm{kg})$ is also considerably below maximum limit allowed $(3.0 \mathrm{mg} / \mathrm{kg})$ [9]. The general content of a toxic element of arsic $(3.5-4.0 \mathrm{mg} / \mathrm{kg})$ is also much lower than maximum limit allowed for Russian soils (TPC $5.0 \mathrm{mg} / \mathrm{kg}$ ). The total content of lead on Plot $2(32.2 \mathrm{mg} / \mathrm{kg}$ ) corresponds to maximum limit allowed level $(32 \mathrm{mg} / \mathrm{kg})$, and other Plots - below maximum limit allowed (5.3-19.2 $\mathrm{mg} \mathrm{kg})$ [13-14].

\section{References}

1. Procedia Environmental Sciences, 24, 35-38 https://doi.org/10.1016/j.proenv.2015.03.006

2. S.N. Adalilar, S. Alkibay, Z. Eser, Procedia Economics and Finance, 23, 539-546 (2015) https://doi.org/10.1016/S2212-5671(15)00561-4

3. Z. Fadeeva, Journal of Cleaner Production, 13(2), 175-189 (2005) https://doi.org/10.1016/S0959-6526(03)00124-0

4. S.N. Volkov, E.V. Cherkashina, D.A. Shapovalov, IOP Conference Series: Earth and Environmental Science, 350, Institute of Physics Publishing (2019) https://doi.org/10.1088/1755-1315/350/1/012074. 
5. J. Awange, Environmental Science and Engineering (Subseries: Environmental Science), Springer, Berlin, Heidelberg, 333-349 (2018) Available at: https://doi.org/10.1007/978-3-319-58418-8_16.

6. E. Zatsepina, O. Sorokina, V. Kosinsky, L. Petrova, I. Fomkin, IV International Scientific and Practical Conference 'Anthropogenic Transformation of Geospace: Nature, Economy, Society' (ATG 2019), 321-325 (2020) https://doi.org/10.2991/aer.k.200202.065.

7. L.E. Petrova, O.A. Sorokina, I.V. Fomkin, E.E. Mamedova, IOP Conf. Series: Earth and Environmental Science, 350, 012042 (2019) DOI: 10.1088/1755$1315 / 350 / 1 / 012042$

8. Y. Wang, A. E.-D. A. Bekhit, J. D. Morton, S. Mason, Nutrients in Dairy and their Implications on Health and Disease (ed. R. R. Watson, R. J. Collier, V. R. Preedy, Academic Press, 363-375, 2017) https://doi.org/10.1016/B978-0-12-809762-5.00028-0

9. J. Dreiucker, W. Vetter, Food Chemistry, 126(2), 762-771 (2011) https://doi.org/10.1016/j.foodchem.2010.11.061

10. S.N. Volkov, D.A. Shapovalov, P.V. Klyushin, V.A. Shirokova, A.O. Khutorova, International Multidisciplinary Scientific GeoConference Surveying Geology and Mining Ecology Management (SGEM), 17, 819-828 (2017) https://doi.org/10.5593/sgem2017/52/S20.105

11. S.P. Zamana, T.G. Fedorovsky, N.A. Golubkina, A.V. Sokolov, IOP Conference Series: Earth and Environmental Science, 350(1), $012047 \quad$ (2019) https://doi.org/10.1088/1755-1315/350/1/012047

12. N.V. Davydova, S.P. Zamana, I.I. Krokhmal, et al., Nanotechnol Russia, 14, 572-581 (2019) https://doi.org/10.1134/S1995078019060041

13. D. la Cecilia, G. M. Porta, F.H.M. Tang, M. Riva, F. Maggi, Ecological Indicators, 115, 106424 (2020) https://doi.org/10.1016/j.ecolind.2020.106424

14. A. Mandal, B. Sarkar, S. Mandal, M. Vithanage, A.K. Patra, M.C. Manna, Agrochemicals Detection, Treatment and Remediation (ed. M.N. Vara Prasad, Butterworth-Heinemann, 161-187, 2020) https://doi.org/10.1016/B978-0-08-1030172.00007-6 